\title{
The impact of maternal HIV infection on cord blood lymphocyte subsets and cytokine profile in exposed non-infected newborns
}

\author{
Eliane Borges-Almeida', Helaine MBPM Milanez², Maria Marluce S Vilela ${ }^{3}$, Fernanda GP Cunha', \\ Beatriz M Abramczuk ${ }^{3}$, Suiellen C Reis-Alves ${ }^{1}$, Konradin Metze ${ }^{4}$, Irene Lorand-Metze ${ }^{5^{*}}$
}

\begin{abstract}
Background: Children born to HIV+ mothers are exposed intra-utero to several drugs and cytokines that can modify the developing immune system, and influence the newborn's immune response to infections and vaccines. We analyzed the relation between the distribution of cord blood lymphocyte subsets and cytokine profile in term newborns of HIV+ mothers using HAART during pregnancy and compared them to normal newborns.

Methods: In a prospective, controlled study, 36 mother-child pairs from HIV+ mothers and 15 HIV-uninfected mothers were studied. Hematological features and cytokine profiles of mothers at 35 weeks of pregnancy were examined. Maternal and cord lymphocyte subsets as well as B-cell maturation in cord blood were analyzed by flow cytometry. The non-stimulated, as well as BCG- and PHA-stimulated production of IL2, IL4, IL7, IL10, IL12, IFN- $\gamma$ and TNF-alpha in mononuclear cell cultures from mothers and infants were quantified using ELISA.

Results: After one year follow-up none of the exposed infants became seropositive for HIV. An increase in B lymphocytes, especially the CD19/CD5+ ones, was observed in cord blood of HIV-exposed newborns. Children of HIV+ hard drug using mothers had also an increase of immature B-cells. Cord blood mononuclear cells of HIVexposed newborns produced less IL-4 and IL-7 and more IL-10 and IFN- $\gamma$ in culture than those of uninfected mothers. Cytokine values in supernatants were similar in infants and their mothers except for IFN- $\gamma$ and TNF-alpha that were higher in HIV+ mothers, especially in drug abusing ones. Cord blood CD19/CD5+ lymphocytes showed a positive correlation with cord IL-7 and IL-10. A higher maternal age and smoking was associated with a decrease of cord blood CD4+ cells.

Conclusions: in uninfected infants born to HIV+ women, several immunological abnormalities were found, related to the residual maternal immune changes induced by the HIV infection and those associated with antiretroviral treatment. Maternal smoking was associated to changes in cord CD3/CD4 lymphocytes and maternal hard drug abuse was associated with more pronounced changes in the cord B cell line.
\end{abstract}

\section{Background}

HIV infection is associated with a complex pattern of changes in the hemopoietic and the immune systems, resulting in abnormalities of peripheral blood (PB) counts and changes in $\mathrm{T}$ and $\mathrm{B}$ lymphocytes. Decrease of $\mathrm{T}$ helper and increase of cytotoxic lymphocytes, profound changes in the cytokine profile and a variety of B

\footnotetext{
* Correspondence: ilmetze@unicamp.br

${ }^{5}$ Hemocentro - State University of Campinas, Rua Carlos Chagas 480, 13083878 Campinas - SP Brazil

Full list of author information is available at the end of the article
}

lymphocyte abnormalities have been repeatedly described [1-4]. However, long term antiretroviral therapy (ARV) is able to restore, at least in part, the immune function [3-6].

The introduction of ARV therapy in HIV+ pregnant women has drastically decreased vertical transmission of HIV [1-7]. But, several changes in PB counts and $\mathrm{T}$ $\mathrm{CD}^{+}$and $\mathrm{CD}^{+}$lymphocytes have been detected in HIV-exposed uninfected newborns $[1,2,4]$ and attributed to alterations in maternal cytokine profile caused by the HIV infection as well as by the ARV treatment [2,8-14].

\section{(Ciomed Central}


PB count changes are soon reversed, but some $\mathrm{T}$ lymphocyte changes may last for as long as 8 years [2]. Therefore, these infants present an increased risk for severe infections. This risk is further increased as newborns from HIV-infected mothers usually do not receive breast feeding in order to avoid vertical transmission. Changes in $\mathrm{T}$ lymphocytes may also affect the response to vaccines given in the neonatal period [2,10-13].

Alterations in infants' $T$ lymphocyte subsets have been well studied, but little is known about the impact of HIV infection and highly active antiretroviral treatment (HAART) on neonatal maturation and function of B lymphocytes $[8,15]$.

The aim of our study was to analyze the B cell maturation in umbilical cord blood of infants born to HIV-infected mothers using HAART. We also studied the relation between the distribution of lymphocyte subsets and cytokine production in short term cultures of cord blood mononuclear cells in as well as in maternal peripheral blood mononuclear cells at 35 weeks of pregnancy. We also looked for the relation between maternal smoking and use of hard drugs during pregnancy and infant's lymphocyte subpopulations.

\section{Methods}

\section{Mother-child pairs}

We studied 36 mother-child pairs of HIV positive pregnant women attended at our High Risk Obstetric Unit. They were $>18$ years old, were using HAART during gestation and had a low or undetectable viral load. All of them had a term delivery. None of the newborns had a malformation at birth. Their data were compared to 15 normal mother-child pairs, which were also attended at our Institution. Mothers of the control group were also $>18$ years old, had no known pathological condition: hypertension, diabetes, obesity, autoimmune disorders, infections, nor a past history of repeated infections suggesting an underlying immunodeficiency, and had a normal term delivery.

Peripheral blood counts as well as cytokine profile of both groups of mothers as well as viral load of the HIV + ones were taken between 32 to 35 weeks of gestation.

After 13-17 months of observation none of the exposed infants developed HIV infection. Infants were considered HIV- uninfected and defined as seroreverters if they had negative HIV- polymerase chain reaction (PCR) tests at 1 and 3 months of age or became HIVseronegative after 13 months of age.

\section{Cord blood analysis}

Cord blood was separated at delivery and processed during the first 24 hours after collection. Cell counts were performed in the hematologic counter Advia 120 (Bayer, Dublin - Ireland). Lymphocyte subsets were studied by flow cytometry. T lymphocytes were analyzed in the CD4/ CD8/CD3 combination. Their number was expressed as percentage of $\mathrm{CD} 3+$ cells among all cord blood nucleated cells. B lymphopoiesis was studied in the combinations: CD5/CD19/CD45, CD45/CD34/CD19/CD22 and sIgM/ CD34/CD19/CD10 (Figure 1). For each case, at least 50000 events were acquired using the FACSCalibur (Beckton Dickinson) equipment (Cell Quest software). Analysis was performed using the Paint-a-Gate software.

\section{Cytokine Assays}

Cytokine assays were performed in supernatants from cultures of peripheral blood mononuclear cells (PBMC) of the mothers at 35 weeks of gestation, and infants' cord blood mononuclear cells (CBMC). In both cases, mononuclear cells were isolated by Ficoll-Hypaque 1077 (Sigma, MO, USA). They were suspended in RPMI 1640 with $10 \%$ human serum, $1 \%$ glutamine and $0.1 \%$ gentamicine and cultured for 48 hours with live Bacillus Calmette-Guérin (BCG) $\left(5 \times 10^{5} / \mathrm{mL}\right)$, (Butantan Institute, SP), phytohemagglutinin (PHA, $7.5 \mu \mathrm{g} / \mathrm{mL}$ ) (Sigma, $\mathrm{MO}, \mathrm{USA}$ ) or in medium alone (non-stimulated).

Cytokines were quantified by enzyme-linked immunosorbent assay (ELISA) in cell-free supernatants using commercial kits for human IL-2, IL-4, IL-7, IL-10, IL12, TNF- $\alpha$ and IFN- $\gamma$ (Duo Set ${ }^{\circledR}$, R\&D Systems Inc, Minneapolis, MN, USA). These cytokines were chosen as they are able to analyze Th1 and Th2 status [15].

\section{T-cell proliferation}

Cord Blood mononuclear cells (CBMC) were isolated by density gradient centrifugation over Ficoll-Hypaque (Amersham Biosciences, USA), washed, diluted to $1 \times$ $10^{6}$ cells/mL in RPMI 1640 medium (Sigma, USA), supplemented with 10\% human AB serum (Sigma, USA), 1\% glutamine (Sigma, USA) and $0.1 \%$ gentamycin and stimulated for 6 days with PHA or medium alone at $37^{\circ} \mathrm{C}$ with 5\% CO2 96-well tissue culture plates (NUNC, Denmark). After harvesting in $20 \mathrm{mM}$ EDTA, samples were incubated with human immunoglobulin and then stained with antihuman CD3, CD4 and CD8 (Beckman Coulter, USA) fluorescent antibodies before acquisition and analysis. Only CD3+ T cells were used in the analysis. Resting and blast lymphocytes were gated on the forward and side scatter plot (Figure 2). Dead cells were excluded from all analyses. CD4+ and CD8+ cells were identified in the gate of blast lymphocytes. Proliferation was measured as percentage of CD3+ blasts in the PHA-stimulated well from which basal proliferation without stimulation was subtracted (PHA, Sigma, USA, $7.5 \mu \mathrm{g} / \mathrm{mL}$ ).

\section{Statistical Analysis}

Features of the normal and HIV-exposed newborns and their mothers were compared by the Mann-Whitney 


\section{A- CD45/CD34/CD19/CD22}

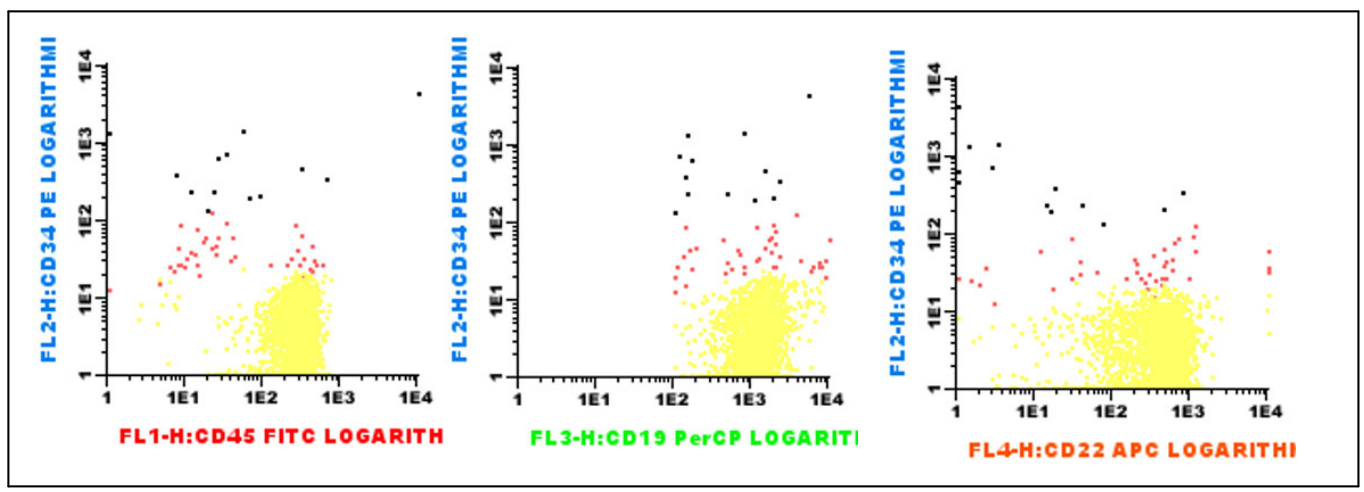

B- $\operatorname{sgM} / \mathrm{CD} 34 / \mathrm{CD} 19 / \mathrm{CD} 10$
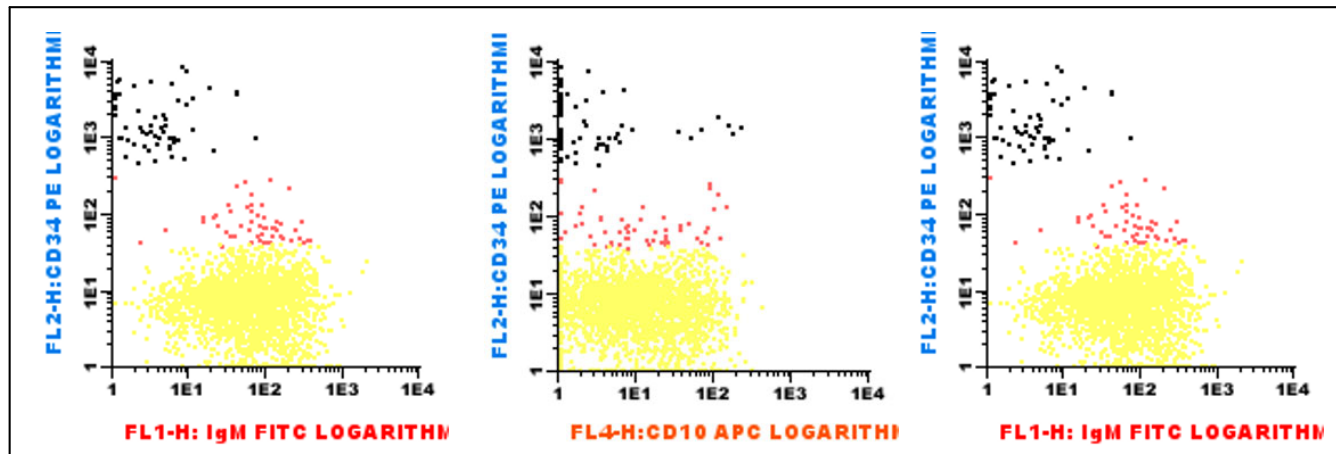

Figure 1 Analysis of B-cell maturation in cord blood of a normal newborn (control group). Expression of CD34 was used to identify immature B-cells. Maturation was studied using the expression of CD45, CD22, CD10 and membrane lgM (slgM). A) CD45/CD34/CD19/CD22 combination - black: immature cells - CD45 ${ }^{\text {low }} \mathrm{CD} 34^{+} \mathrm{CD} 19^{+} \mathrm{CD} 22^{-}$red: intermediate cells - $\mathrm{CD} 45^{-/+} \mathrm{CD} 34^{\text {low }} \mathrm{CD} 19^{+} \mathrm{CD} 22^{+}$yellow: mature cells $\mathrm{CD}_{5}{ }^{+} \mathrm{CD} 34^{-} \mathrm{CD} 19^{+} \mathrm{CD} 22^{+}$. B) slgM/CD34/CD19/CD10 combination - black: immature cells - slgM ${ }^{-} \mathrm{CD} 34^{+} \mathrm{CD} 19^{+} \mathrm{CD} 10^{-/+}$red: intermediate cells slg $^{+} \mathrm{CD} 34^{-/+} \mathrm{CD}_{19} 9^{+} \mathrm{CD} 10^{-/+}$yellow: mature cells - slgM $^{+} \mathrm{CD} 34^{-} \mathrm{CD} 19^{+} \mathrm{CD} 10^{-/+}$.

and Kruskall-Wallis tests. Values were considered statistically significant when the two-sided p-value was < 0.05 . The relationships among the features were examined by the Spearman rank order correlation test. In order to find out which variables were related to birth weight and the $\mathrm{T}$ and $\mathrm{B}$ cell subsets, multiple step-wise linear regressions were run $(0.05$ for input and $\mathrm{p}=$ 0.1 for output, backward conditional stepwise selection) using the variables showing significant differences or correlations in the univariate analysis. Moreover, the $\mathrm{R} 2$ values of each regression, which represent the goodness-of-fit of the mathematical model, were recorded in order to estimate the approximation of the algorithm to clinical and biological reality. Finally, the stability of the model was tested by bootstrap resampling. In this technique we create new data sets of equal size by random sampling of the original data with replacement [16-18]. Thus, in a new bootstrap sample, a patient may be represented once, multiple times or not at all. Then, for each of these "new" sets, a linear regression is calculated and the variables entering each of the "new" models are recorded. This procedure tests the stability of a mathematical model, points out the most important variables and, furthermore, permits to calculate confidence intervals (IC). WinStat 3.1 software was used.

\section{Ethics Approval}

All mothers were invited to participate, received a complete explanation about the aims of the study and written informed consent was obtained according to our local Ethics's Committees (CAISM - Center of Integrated Care for Women's Health, and that of our Faculty of Medicine). 
(A)

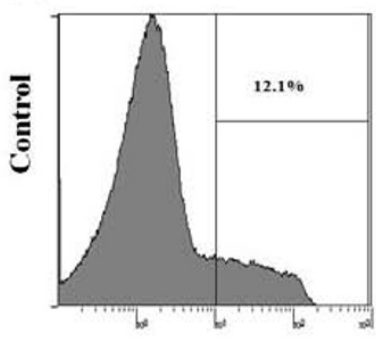

(B)

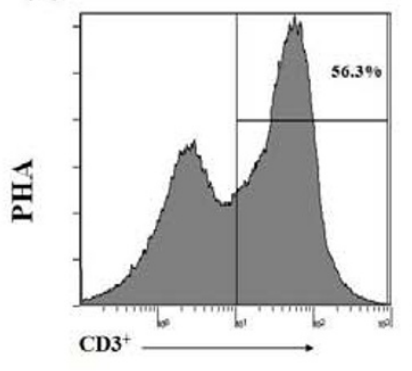

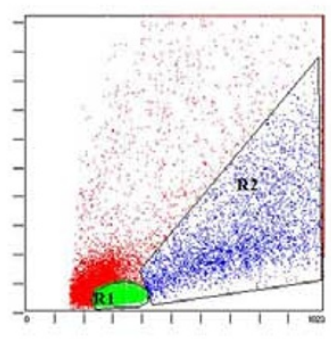

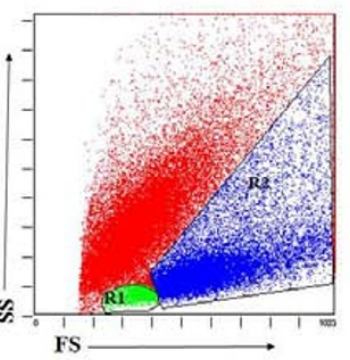

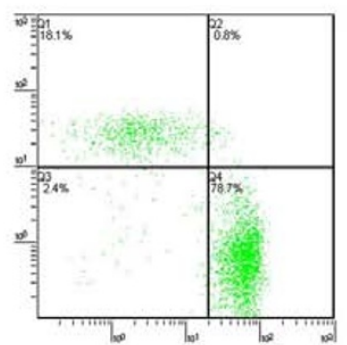
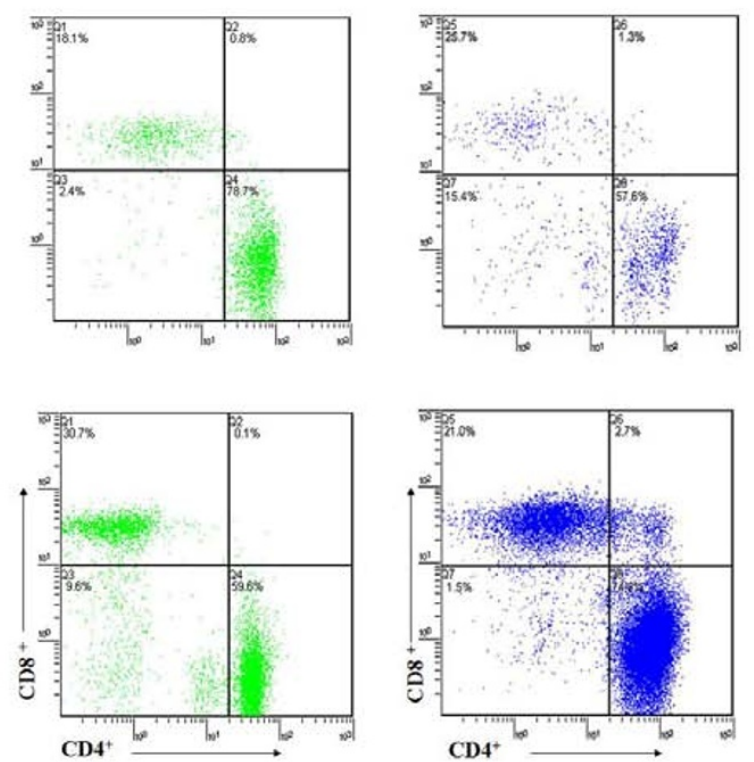

Figure 2 Analysis of T cell proliferation of non-stimulated (A) and PHA-stimulated (B) cord mononuclear cells of a newborn from a HIV-infected mother. After gating of CD3 cells, events were analyzed for size and complexity (forward-scatter and side-scatter gates), from which resting (R1-green) and blast cells (R2-blue) were separated. T-lymphocyte subsets were then analyzed. Dead cells (red) were excluded from all analyses. T cell proliferation was the difference between the percentages of PHA-stimulated blasts and non-stimulated blasts.

\section{Results}

\section{Pregnant women}

The epidemiological features of the mothers entering the study are presented in Table 1 . In the control group, only one mother was a smoker. Yet, smoking and drug abuse (marihuana, cocaine or crack) was common among the HIV+ ones. Both maternal groups had a similar age and a similar time of gestation. HIV+ mothers had a cesarean section in all but one case. Among HIV-negative mothers 11 had a vaginal and 4 a cesarean delivery. Antiretroviral therapy included protease inhibitors in all but 3 cases. Mean time of maternal HAART treatment was 5 months. Eight mothers got pregnant while already using HAART. HIV viral load was undetectable in $23 \mathrm{HIV}+$ mothers and low in the remaining thirteen (Table 1 ).

Mothers' PB counts are shown on Table 2. HIV+ mothers had hemoglobin values similar to that of HIVuninfected ones, but showed a significantly higher mean corpuscular volume (MCV), lower total leukocyte and neutrophil counts. The proportion of $\mathrm{T} \mathrm{CD} 4+$ and T CD8+ lymphocytes of the HIV+ mothers presented similar values in smokers, non-smokers and drug users.

The cytokine concentrations in the supernatant of PBMC cultures not stimulated and after stimulation with BCG and PHA in mothers at 35 weeks of gestation are presented on Table 3. HIV+ mothers showed lower values of IL-4 and IL-7, but higher values of TNF $\alpha$ in non-stimulated cultures. Production of IL-2 and IL12 by PBMCs in non-stimulated as well as stimulated cultures were similar both in normal and HIV-infected mothers.

The CD4/CD8 ratio in PB of HIV+ mothers showed an inverse relation with viral load $(r=-0.30 ; p=0.02)$ and production of TNF $\alpha$ by PBMCs (non-stimulated) $(r=-0.27 ; p=0.04)$ and a direct correlation with IL-10 $(\mathrm{r}=0.35 ; \mathrm{p}=0.01)$. There was no correlation with IL-7.

Table 1 Epidemiologic characteristics of the mothers (median and range)

\begin{tabular}{lcc}
\hline & $\begin{array}{c}\text { HIV negative } \\
\text { (controls) }\end{array}$ & HIV+ mothers \\
\hline Age at delivery (years) & $29(18-41)$ & $32(20-39)$ \\
Weeks of gestation & $39.7(36-42)$ & $38.2(36-42)$ \\
Smoker only & 1 & 5 \\
Drug user only & 0 & 3 \\
Smoker and drug user & 0 & 6 \\
Non-smoker non-drug user & 14 & 22 \\
Days of HAART use & - & $454(49-273)$ \\
detectable viral load copies/ & - & $36586)$ \\
mL* & & $454-$ \\
\hline
\end{tabular}

* among 13 mothers with a detectable viral load. 
Table 2 Peripheral blood features of the mothers at 35 weeks of pregnancy (median and range)

\begin{tabular}{|c|c|c|c|}
\hline & $\begin{array}{l}\text { HIV negative } \\
\text { mothers }\end{array}$ & $\begin{array}{c}\text { HIV+ } \\
\text { mothers }\end{array}$ & $\begin{array}{c}p \\
\text { value }\end{array}$ \\
\hline \multirow[t]{2}{*}{$\mathrm{RBC}^{*}(\mathrm{M} / \mu \mathrm{L})$} & 3.9 & 3.3 & $<0.005$ \\
\hline & $(3.7-4.7)$ & $(2.5-4.7)$ & \\
\hline \multirow[t]{2}{*}{$H B^{*}(g / d L)$} & 11.7 & 10.7 & 0.09 \\
\hline & $(9.6-13.9)$ & $(9.0-13.7)$ & \\
\hline \multirow[t]{2}{*}{$M \mathrm{CV}^{*}(\mathrm{fL})$} & 88 & 104 & $<0.005$ \\
\hline & $(72-94)$ & $(75-118)$ & \\
\hline \multirow[t]{2}{*}{$W B C^{*}(K / \mu L)$} & 8.2 & 7.2 & 0.04 \\
\hline & $(3.2-12.2)$ & $(3.0-15.0)$ & \\
\hline \multirow[t]{2}{*}{ Total neutrophils $(\mathrm{K} / \mu \mathrm{L})$} & 5.7 & 4.86 & 0.07 \\
\hline & $(2.3-8.8)$ & $(2.2-10.9)$ & \\
\hline \multirow{2}{*}{$\begin{array}{l}\text { Total lymphocytes (KV } \\
\mu \mathrm{L})\end{array}$} & 1.8 & 1.6 & 0.94 \\
\hline & $(0.6-2.7)$ & $(0.5-4.8)$ & \\
\hline \multirow[t]{2}{*}{ CD4+ count } & n.d.* & 511 & \\
\hline & & $(57-1189)$ & \\
\hline \multirow[t]{2}{*}{ CD8+ count } & n.d.* & 676 & \\
\hline & & $(321-1979)$ & \\
\hline \multirow[t]{2}{*}{ CD4/CD8 ratio } & n.d.* & 0.73 & \\
\hline & & $(0.06-1.97)$ & \\
\hline \multirow[t]{2}{*}{ Platelets $(\mathrm{K} / \mu \mathrm{L})$} & 200 & 217 & 0.96 \\
\hline & $(102-392)$ & $(99-360)$ & \\
\hline
\end{tabular}

* RBC = red blood cells; $\mathrm{HB}=$ hemoglobin; $\mathrm{MCV}=$ mean corpuscular volume; WBC = leukocytes; $n . d=$ not done.

In a multiple regression, we obtained the formula:

Maternal CD4/CD8 ratio $=0.946+5.6 \times 10^{-5} \times \mathrm{IL}-$ $10-9.8 \times 10^{-5} \times \mathrm{TNF} \alpha-0.0567 \times \log$ viral load + $0.9468 \mathrm{R}^{2}=0.335 ; \mathrm{p}=0.004$

The stability of the model was confirmed in a bootstrap resampling procedure. Among 100 new models, "log viral load" entered in 97\%, "IL-10" level in 89\%, "TNF $\alpha$ " in $60 \%$ and "IL-7" in $28 \%$ of them.

\section{Newborns}

The birth data of the newborns are described in Table 4. Children of HIV+ mothers had a similar height but a lower weight than those born to uninfected mothers. Furthermore, they had lower hemoglobin levels, a higher MCV and lower leukocyte and neutrophil counts than non-exposed newborns. The number of days of maternal ARV treatment during pregnancy did not influence these values, but there was a good correlation between maternal and cord blood red blood cells (RBCs) ( $\mathrm{r}=0.56$; $\mathrm{p}<$ $0.0005)$ and $\mathrm{MCV}(\mathrm{r}=0.54 ; \mathrm{p}<0.0005)$. This was less evident concerning hemoglobin values $(\mathrm{r}=0.21 ; \mathrm{p}=0.06)$.

The birth weight of HIV-exposed infants showed a relation with the duration of maternal HAART treatment during pregnancy and the TNF $\alpha$ production (nonstimulated cultures) in supernatants of cultures of $\mathrm{PB}$ mononuclear cells collected at the end of gestation.
Table 3 Cytokine levels (in $\mathrm{pg} / \mathrm{ml}$, median and range) without antigenic stimulus and after stimulation with BCG and PHA in the supernatant from mothers' peripheral mononuclear cell cultures collected at 35 weeks of gestation

\begin{tabular}{|c|c|c|c|}
\hline & $\begin{array}{l}\text { HIV-uninfected } \\
\text { controls }\end{array}$ & HIV+ mothers & $\begin{array}{c}p \\
\text { value }\end{array}$ \\
\hline $\begin{array}{l}\text { IL-2 non- } \\
\text { stimulated }\end{array}$ & $0.0(0-76)$ & $0.0(0-767)$ & 0.47 \\
\hline $\mathrm{BCG}$ & $0.0(0-78)$ & $2.14(0-232)$ & 0.44 \\
\hline $\mathrm{PHA}$ & $89.8(0-968)$ & $24.5(0-1421)$ & 0.34 \\
\hline $\begin{array}{l}\text { IL-4 non- } \\
\text { stimulated }\end{array}$ & $41.0(38-278)$ & $22.2(9.2-76)$ & $<0.005$ \\
\hline$B C G$ & $39.1(37-216)$ & $22.8(9.5-76)$ & $<0.005$ \\
\hline $\mathrm{PHA}$ & $52.0(39-146)$ & $30.14(14-419)$ & $<0.005$ \\
\hline $\begin{array}{l}\text { IL-7 non- } \\
\text { stimulated }\end{array}$ & $67.0(0-88)$ & $0.0(0-90)$ & 0.05 \\
\hline $\mathrm{BCG}$ & $66.0(0-89)$ & $0.0(0-86)$ & 0.04 \\
\hline $\mathrm{PHA}$ & $66.0(0-85)$ & $0.0(0-87)$ & 0.03 \\
\hline $\begin{array}{l}\text { IL-10 non- } \\
\text { stimulated }\end{array}$ & $0.0(0-490)$ & $17(0-18015)$ & 0.14 \\
\hline BCG & $736(0-4910)$ & 764 (0 - 43384) & 0.49 \\
\hline PHA & $498(0-2925)$ & $405(0-58344)$ & 0.56 \\
\hline $\begin{array}{l}\text { IL-12 non- } \\
\text { stimulated }\end{array}$ & $0.51(0-2.83)$ & $0.51(0-2.4)$ & 0.62 \\
\hline BCG & $1.18(1-31)$ & $1.0(0-11)$ & 0.27 \\
\hline $\mathrm{PHA}$ & $1.34(0-51)$ & $1.53(0-33)$ & 0.68 \\
\hline $\begin{array}{l}\text { IFN } \gamma \text { non- } \\
\text { stimulated }\end{array}$ & $0.0(0-94)$ & $13.2(0-131)$ & 0.73 \\
\hline$B C G$ & $2.73(0-1343)$ & $29.2(0-999)$ & 0.42 \\
\hline $\mathrm{PHA}$ & $110.2(0-2528)$ & $308.9(0-5143)$ & 0.16 \\
\hline $\begin{array}{l}\text { TNF } \alpha \text { non- } \\
\text { stimulated }\end{array}$ & $245.4(0-4826)$ & $526.8(0-7928)$ & $<0.0005$ \\
\hline $\mathrm{BCG}$ & $5374.0(0-13852)$ & $\begin{array}{c}2072.7(86- \\
34130)\end{array}$ & 0.83 \\
\hline $\mathrm{PHA}$ & 827.6 (261 - 20889) & $\begin{array}{c}1513.3(244- \\
14448)\end{array}$ & 0.22 \\
\hline
\end{tabular}

Maternal age, smoking, weeks of gestation and child's gender had no relation to birth weight.

In a multiple regression we obtained the formula:

Birth weight $=3327-1.48 \times$ days of HAART $-5 \times$ unstimulated maternal TNF $\alpha \mathrm{p}=0.006, \mathrm{R}^{2}=0.216$ ( CI $95 \%: 0.215-0.383$ )

The bootstrap resampling study confirmed this result: "days of HAART treatment" appeared in 77\% and "nonstimulated maternal TNF $\alpha$ at 35 weeks of gestation" was present in $70 \%$ of the new data sets. But, "weeks of gestation" appeared in 40\%, "maternal smoking" in 38\%, "mother's age" in $12 \%$ and "child's gender" in $10 \%$ of the new data sets.

The distribution of the several lymphocyte subsets in cord blood is shown on Table 4. The percentage of CD3 + lymphocytes in HIV-exposed newborns was increased when compared with the non-exposed ones. The CD4/ CD8 ratio was significantly lower. 
Table 4 Birth data, cord blood counts and lymphocyte subsets of the newborns (median and range)

\begin{tabular}{|c|c|c|c|}
\hline & Not exposed (controls) & HIV - exposed & $p$ value \\
\hline \multirow[t]{2}{*}{ Weight (grams) } & 3100 & 2962 & $<0.005$ \\
\hline & $(2988-3915)$ & $(1885-3885)$ & \\
\hline \multirow[t]{2}{*}{ Height (cm) } & 48 & 48 & 0.87 \\
\hline & $(40-53)$ & $(33-53)$ & \\
\hline \multirow[t]{2}{*}{ Capurro score } & 278 & 267 & $<0.005$ \\
\hline & $(256-294)$ & $(255-293)$ & \\
\hline \multirow[t]{2}{*}{$\mathrm{RBC}(\mathrm{M} / \mu \mathrm{L})$} & 4.6 & 3.5 & $<0.005$ \\
\hline & $(4.1-5.0)$ & $(2.7-4.7)$ & \\
\hline \multirow[t]{2}{*}{$\mathrm{HB}(\mathrm{g} / \mathrm{dL})$} & 15.7 & 13.7 & $<0.005$ \\
\hline & $(13.2-18.0)$ & $(9.1-16.4)$ & \\
\hline \multirow[t]{2}{*}{$\mathrm{MCV}(\mathrm{fL})$} & 104 & 117 & $<0.005$ \\
\hline & $(99-124)$ & $(88-150)$ & \\
\hline \multirow[t]{2}{*}{ Platelets $(\mathrm{K} / \mu \mathrm{L})$} & 202 & 242 & 0.12 \\
\hline & $(119-328)$ & $(103-455)$ & \\
\hline \multirow[t]{2}{*}{ 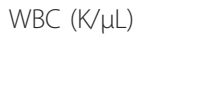 } & 11.1 & 9.1 & 0.08 \\
\hline & $(4.4-19.5)$ & $(4.0-22.0)$ & \\
\hline \multirow{2}{*}{$\begin{array}{l}\text { Total neutrophils } \\
(\mathrm{K} / \mu \mathrm{L})\end{array}$} & 4.2 & 3.5 & 0.32 \\
\hline & $(0.8-9.4)$ & $(1.0-8.8)$ & \\
\hline \multirow{2}{*}{$\begin{array}{l}\text { Total lymphocytes } \\
(\mathrm{K} / \mu \mathrm{L})\end{array}$} & 5.7 & 5.1 & 0.16 \\
\hline & $(3.0-9.1)$ & $(1.5-10.5)$ & \\
\hline \multirow[t]{2}{*}{$\%$ CD3+ } & 18.3 & 24.8 & 0.03 \\
\hline & $(13.8-32.3)$ & $(12.0-41.5)$ & \\
\hline \multirow[t]{2}{*}{$\%$ CD3/CD4+ } & 12.6 & 17.2 & 0.32 \\
\hline & $(8.9-23.3)$ & $(3.0-28.2)$ & \\
\hline \multirow[t]{2}{*}{$\%$ CD3+/CD8+ } & 4.6 & 6.4 & 0.002 \\
\hline & $(1.8-10.7)$ & $(2.3-15.5)$ & \\
\hline \multirow[t]{2}{*}{ CD4/CD8 ratio } & 3.5 & 2.3 & 0.04 \\
\hline & $(1.6-8.3)$ & $(0.2-6.5)$ & \\
\hline \multirow[t]{2}{*}{ \% CD19+ } & 3.6 & 5.7 & 0.01 \\
\hline & $(2.0-5.9)$ & $(1.7-16.2)$ & \\
\hline \multirow[t]{2}{*}{$\%$ CD19+CD5+ ** } & 59.5 & 75.8 & 0.006 \\
\hline & $(42.8-91.1)$ & $(47.7-97.0)$ & \\
\hline
\end{tabular}

${ }^{*} \mathrm{RBC}=$ red blood cells; $\mathrm{HB}=$ hemoglobin; $\mathrm{MCV}=$ mean corpuscular volume WBC $=$ leukocytes, ${ }^{* *}$ among all CD19+ cells.

In HIV-exposed neonates the relation of the number of cord T lymphocytes with maternal age, days of HAART use during pregnancy, smoking and drug abuse was examined in a multiple regression. For T CD8+ cell no model could be obtained.

The percentage of T CD4+ cells was lower in children from older and smoking mothers.

This percentage could be calculated by the formula:

Cord \% T CD4+ cells $=-0.428 \times$ mother's age $($ years $)$ $-4.91(\mathrm{~S})+30.52$;

$\mathrm{S}=1$ for smoking and 0 for non-smoking mother.

$\mathrm{R}^{2}=0.242(\mathrm{CI}$ 95\%: 16.6 - 51.1)

Drug abuse and days of maternal HAART treatment during pregnancy did not enter the model. The stability of the model for cord blood T CD4+ cells was confirmed in the bootstrap resampling. Among 100 new models, "maternal age" entered in $87 \%$ and "maternal smoking" in $72 \%$ of them. "Duration of maternal HAART treatment" entered in $42 \%$, and "drug abuse" in $11 \%$ of the models.

CD3, CD4 and CD8 immunophenotyping was carried out in cell cultures of cord blood from 22 newborns from HIV + mothers and 10 non-exposed ones. Median background CD3+ proliferation was 9.6\% (0.5-25.9) in the HIV+ group and $10.4 \%(6.2-91.7)$ in the controls $(\mathrm{p}=0.44)$. The blast percentage in PHA-stimulated cultures showed a median of $40.3 \%$ (1.5-71.6) for the HIV+ group and 54.2 (11.7-74.8) for the non-exposed controls. The proportion of PHA-proliferating CD4+ and CD8+ cells were not different between the groups (Table 5).

Cord blood CD19+ lymphocytes (Table 6) were increased in newborns of HIV+ mothers due to an increase of CD19+/CD5+ cells. Children of drug users had the highest numbers of total B lymphocytes. The duration of HAART during pregnancy showed no correlation with the total number of cord blood B-cells or with that of CD19+/CD5+ ones.

B-cell maturation was analyzed in two four-color combinations (Table 6). The CD45/CD34/CD19/ CD22 combination was the most useful to reveal an increase in immature and intermediary B-precursors in infants of HIV+ mothers. This feature was more pronounced in children of drug users.

In HIV-exposed neonates, there was no significant difference in the proportion of immature cells with the newborn's gender $(p=0.33)$ or children of smokers and non-smokers $(\mathrm{p}=0.21)$, but those of drug users showed a higher percentage $(\mathrm{p}=0.007)$ (Table 6). There was no significant correlation between this variable and gestation duration or maternal age but with the number of days of maternal HAART use $(r=0.53 ; \mathrm{p}=0.01)$.

In a multiple regression, examining the relation between the percentage of cord blood immature cells with maternal drug abuse and the number of days of HAART treatment during pregnancy, the proportion of

Table 5 Percentages of CD4+ and CD8+ blastic cells determined by flow cytometry in $\mathrm{CBMC}^{\mathrm{a}}$ cultures incubated with $\mathrm{PHA}^{\mathrm{b}}$ from 22 newborns from HIV+ mothers and 10 HIV negative controls (median and range)

\begin{tabular}{cccc}
\hline T cells & Non exposed controls & HIV exposed & p value \\
\hline CD4+ & 88.6 & 86.3 & 0.807 \\
& $(3.4-97.2)$ & $(1.7-98.3)$ & \\
CD8+ & 6.2 & 7.6 & 1.00 \\
& $(1.4-79.5)$ & $(0.3-92.7)$ & \\
\hline
\end{tabular}

${ }^{\mathrm{a}}$ cord blood mononuclear cells; ${ }^{\mathrm{b}}$ Phytohemaglutinin. 
Table 6 B lymphocyte subsets and B-cell maturation in cord blood studied in the CD45/CD34/CD19/CD22 and slgM/ CD34/CD19/CD10 combinations (median and range)

\begin{tabular}{|c|c|c|c|c|}
\hline & Non exposed controls & HIV exposed & HIV exposed drug using mother & $\mathrm{p}$ value \\
\hline$\% \mathrm{CD}_{1} 9^{+}$ & 3.6 & 5.2 & 7.0 & 0.01 \\
\hline$\% \mathrm{CD}_{19} \mathrm{CD}^{+} 5^{*}$ & 59.5 & 77.8 & 67.6 & 0.007 \\
\hline \multirow[t]{2}{*}{$\% \mathrm{CD} 45^{\mathrm{low}} \mathrm{CD} 34^{+} \mathrm{CD} 19^{+} \mathrm{CD} 22^{-/+} * *$} & 0.73 & 0.42 & 1.1 & \\
\hline & $(0.2-3.13)$ & $(0.07-1.22)$ & $(0.78-1.4)$ & 0.01 \\
\hline \multirow[t]{2}{*}{$\% \mathrm{CD}_{4} 5^{-/+} \mathrm{CD} 34^{\mathrm{low}} \mathrm{CD} 19^{+} \mathrm{CD} 22^{+* * *}$} & 2.62 & 2.94 & 13.0 & \\
\hline & $(0.24-6.8)$ & $(1.5-8.2)$ & $(8.8-19.4)$ & 0.01 \\
\hline \multirow[t]{2}{*}{$\% \mathrm{CD}^{2} 5^{+} \mathrm{CD} 34{ }^{-} \mathrm{CD} 19^{+} \mathrm{CD} 22^{+* * * *}$} & 96.7 & 96.7 & 86.3 & \\
\hline & $(91-99)$ & $(91.6-98.4)$ & $(79-90)$ & 0.02 \\
\hline \multirow[t]{2}{*}{$\%$ slgM ${ }^{-} \mathrm{CD} 34^{+} \mathrm{CD} 19^{+} \mathrm{CD} 10^{-/+* *}$} & 0.4 & 0.2 & 1.5 & \\
\hline & $(0.10-2.2)$ & $(0.05-0.95)$ & $(0.4-2.7)$ & 0.05 \\
\hline \multirow[t]{2}{*}{$\% \mathrm{slgM}^{+} \mathrm{CD} 34^{-/+} \mathrm{CD}_{19} \mathrm{CD}^{+} 0^{-/+} * * *$} & 2.4 & 2.2 & 6.5 & \\
\hline & $(0.87-7.1)$ & $(0.6-4.5)$ & $(2.1-71)$ & 0.13 \\
\hline \multirow[t]{2}{*}{$\%$ slg ${ }^{+} \mathrm{CD} 34^{-} \mathrm{CD} 19^{+} \mathrm{CD} 10^{-/+* * * *}$} & 97.1 & 97.3 & 92.5 & \\
\hline & $(91.3-98.9)$ & $(94.6-99.3)$ & $(92.0-95.0)$ & 0.05 \\
\hline
\end{tabular}

* percentage of the total $\mathrm{CD} 19^{+}$cells, ${ }^{* *}$ immature cells, ${ }^{* *}$ intermediary and ${ }^{* * *}$ mature B-cells.

immature/intermediate (IMAT) B cells could be calculated by the formula:

$\%$ Cord IMAT B cells $=0.02 \times$ days of HAART $+\mathrm{B}+$ $0.72 ; R^{2}=0.859(\mathrm{CI}-0.653-0.943)$

With $\mathrm{B}=12.0$ for drug abusers and $\mathrm{B}=0$ for all other mothers.

The stability of this regression model was tested by the bootstrap resampling study, where both variables entered in $98 \%$ of the new data sets.

The cytokine concentrations in the supernatant of CBMC cultures (Table 7) showed a high correlation with the values found for their mothers (Table 3), excluding those of IFN $\gamma$ and TNF $\alpha$. IL-4 and IL-7 production was lower in HIV+ mothers and cord blood mononuclear cells. Concerning IL-10, there was no significant difference between HIV+ and HIV negative mothers. However, HIV-exposed newborns produced higher amounts than non-exposed, although these differences had a low statistical significance.

Concerning TNF $\alpha$, HIV+ mothers had a higher production, especially drug users $(p=0.01)$. CBMCs of HIV-exposed infants produced similar amounts of TNF $\alpha$ but more IFN $\gamma$ than the control group. No correlation was found between the number of days of maternal HAART treatment during pregnancy and CBMC cytokine production.

In non-exposed newborns, no correlation was found between the percentage of CD19+ cells as well as CD19 $+/ C D 5+$ ones and any cytokine production in CBMCs. However, in HIV-exposed newborns, an inverse correlation was found between total cord blood CD19+ cells and cord IL-4 and IL-7 production in nonstimulated cultures (Table 8).
Table 7 Cytokine levels (in $\mathrm{pg} / \mathrm{ml}$, median and range) without antigenic stimulus and after stimulation with BCG and PHA in the supernatant of cord blood cell cultures

\begin{tabular}{|c|c|c|c|}
\hline & $\begin{array}{l}\text { Non-exposed } \\
\text { newborns }\end{array}$ & $\begin{array}{l}\text { HIV-exposed } \\
\text { newborns }\end{array}$ & $\begin{array}{c}p \\
\text { value }\end{array}$ \\
\hline $\begin{array}{l}\text { IL-2 non- } \\
\text { stimulated }\end{array}$ & $0.0(0-76)$ & $0.72(0-81)$ & 0.13 \\
\hline BCG & $0.0(0-78)$ & $0.36(0-79)$ & 0.54 \\
\hline PHA & $43.7(0-1278)$ & $18.9(0-5936)$ & 0.46 \\
\hline $\begin{array}{l}\text { IL-4 non- } \\
\text { stimulated }\end{array}$ & $39.2(39-76)$ & $25.5(10-76)$ & $<0.005$ \\
\hline BCG & $39.4(40-76)$ & $25.6(9-76)$ & $<0.005$ \\
\hline PHA & $39.2(39-78)$ & $26.7(9.5-76)$ & $<0.005$ \\
\hline $\begin{array}{l}\text { IL-7 non- } \\
\text { stimulated }\end{array}$ & $66.0(0-87)$ & $0.0(0-87)$ & 0.13 \\
\hline BCG & $66.4(0-87)$ & $1.5(0-93)$ & 0.24 \\
\hline $\mathrm{PHA}$ & $66.5(0-87)$ & $0.0(0.0-88)$ & 0.11 \\
\hline $\begin{array}{l}\text { IL-10 non- } \\
\text { stimulated }\end{array}$ & $0(0-88)$ & $3.5(0-1028)$ & 0.13 \\
\hline BCG & $199(0-1522)$ & $582(0-7049)$ & 0.06 \\
\hline PHA & $224(0-1934)$ & $410(0-36093)$ & 0.19 \\
\hline $\begin{array}{l}\text { IL-12 non- } \\
\text { stimulated }\end{array}$ & $0.66(0-13.3)$ & $0.24(0-5.7)$ & 0.41 \\
\hline BCG & $0.83(0-26)$ & $0.74(0-3.64)$ & 0.10 \\
\hline PHA & $0.62(0-3)$ & $1.1(0-8)$ & 0.58 \\
\hline $\begin{array}{l}\text { IFN } \gamma \text { non- } \\
\text { stimulated }\end{array}$ & $0.0(0-66)$ & $17.5(0-194)$ & 0.01 \\
\hline BCG & $0.0(0-1188)$ & $19.4(0-550)$ & 0.02 \\
\hline $\mathrm{PHA}$ & $24.3(0-2445)$ & $73.2(0-2928)$ & 0.28 \\
\hline $\begin{array}{l}\text { TNF } \alpha \text { non- } \\
\text { stimulated }\end{array}$ & $136.4(0-500)$ & $181.6(0-3381)$ & 0.66 \\
\hline BCG & $1458.1(138-7026)$ & $1069.0(283-14724)$ & 0.96 \\
\hline PHA & $535.0(298-5672)$ & $658.4(0-6313)$ & 0.63 \\
\hline
\end{tabular}




\begin{tabular}{|c|c|c|}
\hline & CD19+ cells & CD19+/CD5+ cells \\
\hline IL-4 non-stimulated & $r=-0.49 ; p=0.001$ & $r=0.25 ; p=0.07$ \\
\hline BCG & $r=-0.46 ; p=0.002$ & n.s. ${ }^{*}$ \\
\hline $\mathrm{PHA}$ & $r=-0.40 ; p=0.008$ & n.s. ${ }^{*}$ \\
\hline IL-7 non-stimulated & $r=-0.46 ; p=0.002$ & $r=0.32 ; p=0.02$ \\
\hline BCG & $r=-0.39 ; p=0.01$ & $r=0.41 ; p=0.006$ \\
\hline $\mathrm{PHA}$ & $r=-0.48 ; p=0.001$ & $r=0.45 ; p=0.003$ \\
\hline IL-10 non-stimulated & $r=-0.31 ; p=0.05^{* *}$ & $r=0.33 ; p=0.02$ \\
\hline BCG & $r=-0.48 ; p=0.02^{* *}$ & $r=0.51 ; p<0.0005$ \\
\hline $\mathrm{PHA}$ & $r=-0.39 ; p=0.04^{* *}$ & $r=0.41 ; p=0.03$ \\
\hline
\end{tabular}

* not significant; ${ }^{* *}$ considering only immature/intermediary B-cells.

A positive correlation was seen between CD19+/CD5+ cells and cord IL-7 and IL-10, but no correlation was found between these cells and production of IL-4, IFN $\gamma$ and TNF $\alpha$ by CBMCs.

\section{Discussion}

HIV-exposed uninfected infants present a variety of small but significant alterations compared to nonexposed neonates such as a lower birth weight, peripheral blood cytopenias and distribution pattern of circulating lymphocyte subsets $[1,2,4,5,10,19-25]$. Their lower birth weight has been attributed to an earlier delivery due to a higher rate of elective cesarean section [10] or to an earlier maternal Th2 to Th1 shift related to the antretroviral treatment leading to a premature delivery [15]. In our study however, the gestation period was similar in both groups despite that HIV+ mothers delivered by an elective cesarean section. Low weight at birth of HIV-exposed infants was associated to a high maternal production of TNF $\alpha$ at the end of pregnancy, which was more common in drug abusing mothers. It has been shown that neither HAART nor decreased IL-10 levels, but only increase in maternal IL-2 is associated to a premature delivery [26-28]. To the best of our knowledge there are no data in the literature about the relation between maternal IL-7 and IL-4 and low birth weight and prematurity. In our study, a better control of the maternal HIV infection, expressed by an increase of the CD4/CD8 ratio, was also associated with a lower production of TNF $\alpha$ and higher one of IL-10.

In our prospective controlled trial we compared hematological and immunological features of term newborns from HIV+ women under effective HAART treatment during pregnancy with normal unexposed newborns. Hemoglobin, leukocyte and neutrophil counts were lower, and MCV was higher. These alterations were similar to those described in the literature $[1,2,4,10]$, and could be readily explained by maternal HAART treatment and placental drug transfer, as it has been already pointed out $[4,25]$. We could not demonstrate an association of the intensity of the newborns' peripheral cytopenias with the duration of maternal HAART treatment, but when maternal and newborns' $\mathrm{PB}$ counts were compared, RBC and MCV showed a significant correlation. We could not find any correlation concerning leukocytes and platelets. Our study cohort was rather small, but other factors, such as maternal nutritional status or use of antibacterial medications could have influenced the PB counts found.

We could also detect several differences in cord blood lymphocyte sub-populations in our HIV-exposed uninfected newborns when compared to children from HIV negative mothers. We studied the possible association of these alterations with the maternal and cord blood cytokine profile, duration of maternal HAART treatment as well as maternal smoking and drug abuse.

Concerning maternal cytokine profile, HIV+ women only differed from uninfected ones by a lower production of IL-4 and IL-7 in culture, but more TNF $\alpha$, especially in drug using women. A decrease in the Th2 cytokine profile has been described at the end of pregnancy [26]. On the other hand, antiretroviral drugs, especially protease inhibitors as used in the present study, have been associated to a metabolic syndrome associated with an activation of pro-inflammatory cytokines, mainly TNFa [27]. We may speculate that the co-occurrence of maternal HIV-1 infection, use of HAART and hard drugs, all contributed to a higher stimulation of maternal immune cells leading to a larger baseline production of TNF- $\alpha$ in short term culture. The reduced production of IL-4 and IL-7 observed in HIV-infected mothers is in keeping with a change in T-lymphocyte homeostasis in HIV-infected patients.

The decrease of IL- 4 and increase of IFN- $\gamma$ in HIVexposed uninfected newborns speaks in favor of an environment with a Th1-shifted balance. This is more pronounced in newborns of HIV+ mothers under effective HAART $[4,6,11,12]$. This treatment has been associated with an at least a partial restoration of the immune function in HIV infected children and adult patients [19-22].

Our results confirmed previous findings of changes in $\mathrm{T}$-cell development in cord blood of uninfected newborns of HIV - infected mothers with undetectable or low viral load [2,9-11]. Our HIV-exposed uninfected newborns presented higher numbers of $\mathrm{CD}^{+}$cells, due mainly to increase in $\mathrm{CD} 8^{+}$lymphocytes as is seen in $\mathrm{HIV}$-infected adults. Lower proportions of $\mathrm{CD} 4^{+}$, but not of $\mathrm{CD}^{+} \mathrm{T}$ cells was also associated to a higher maternal age and smoking. Although we examined only a small number of patients, these findings are in keeping 
with those found in adult smokers [29,30]. Therefore, not only the maternal HIV infection could alter the thymus function of exposed infants, but also maternal smoking.

Placental transfer of HIV-related proteins and residual maternal immune alterations could be responsible for the findings concerning the immune function of our HIV-exposed non-infected neonates [31,32]. On the other hand, 11/15 of the healthy control mothers in our study had a normal vaginal delivery, while all except one of the HIV-infected mothers had a cesarean section. Therefore, some differences found between HIVexposed and non-exposed neonates may be explained by the different mode of delivery of both groups of newborns. It has been shown that normal labor induces immune stimulation in mothers and neonates including a higher production of TNF- $\alpha$ [33]. This could explain the difference found of this cytokine in supernatants of maternal but not in cord mononuclear cultures, as normal newborns were stimulated by labor and HIVexposed ones were already stimulated by the maternal HIV infection.

The long term CBMC cultures demonstrated similar numbers of T-derived activated cells after PHA stimulation in HIV-exposed neonates and non-exposed ones. Similar proportions of CD4+ and CD8+ cells were also observed in HIV-exposed uninfected newborns and unexposed ones, speaking in favor of a preserved function of these cells.

Cord blood B lymphocytes were increased in HIVexposed neonates, mainly caused by an increase in CD19+/CD5+ cells. A B-cell dysfunction with appearance of immature/transitional B-cells and hypergammaglobulinemia has also been described in active HIV infection in adults $[8,20,34-36]$. There are some discrepancies in the literature concerning the change in number of these cells in adult HIV-infected patients [19-24]. However, long-term response to HAART seems to restore at least partially, the number and function of these cells $[8,10,12,19,20]$. In the present study, the number of CD5+ B lymphocytes was correlated directly with production of IL-7 and IL-10 by CBMCs. CD5 is a negative regulator of the $\mathrm{B}$-cell receptor signaling contributing to a prolonged cell survival and maintaining tolerance in anergic B cells in vivo [37]. In cord blood, CD5+ B lymphocytes represent about half of the B cells [38]. The increase of CD5+ B lymphocytes in our HIVexposed newborns may be an expression of an immune deregulation due to placental transfer of viral proteins and cytokines. How these changes may affect the neonatal development of HIV-exposed uninfected children is not known, but a reduced response to neonatal vaccines has been reported [13]. So, the changes found in our HIV-exposed newborns indicate that, although HAART controlled maternal HIV infection, leading to low or undetectable viral load at 35 weeks of pregnancy, children still had changes in B lymphocytes, consistent with some remaining HIV-mediated immune abnormalities.

We studied B-cell maturation in cord blood using four-color-antibody combinations proposed by van Lochen et al [39]. Only the combinations that examined the initial maturation of the $\mathrm{B}$ cell line were able to disclose differences between normal newborns and those born to HIV+ mothers. Especially maternal drug abuse and a longer period of maternal HAART treatment during pregnancy were associated with a larger number of immature B-cells. This could be a sign of a higher fetal burden of HIV-related proteins and TNFa [33]. Little is known about the influence of cocaine on the immune system, although some earlier studies [40] have shown a smaller stimulation of cord lymphocytes by PHA and PMA and lower levels of IL-1 and IL-2 in cord blood from newborns of drug abusing mothers.

\section{Conclusions}

We conclude that in our study setting, uninfected infants born to HIV+ women, several immunological abnormalities could be detected. They were related to the residual maternal immune changes caused by the HIV infection as well as the use of antiretroviral drugs during pregnancy. Maternal smoking was associated to changes in cord $\mathrm{CD} 3 / \mathrm{CD} 4$ cells, and maternal hard drug abuse was associated to more pronounced changes in the cord B cell line. Immunological changes in uninfected infants born to HIV+ women may persist for several years [2,9-11]. Little is known about their long term clinical significance. It would be interesting to examine in detail the evolution of the PB lymphocyte subsets in our study cohort. The role of maternal smoking and drug abuse on the development of the immune system of their offspring should also be studied in larger cohorts of mother-child pairs.

\section{Acknowledgements}

This work was supported by a grant from FAPESP (São Paulo Research Foundation - project 2006/52596-0) and a grant from the National Council of Technological and Scientific Development (CNPq project 304586/2006-4). ILM and KM have a reseach grant from CNPq. We thank the colleagues of the Obstetric Unit (Dr Eliana Martorano Amaral) and the Neonatal Unit (Dr Sérgio Tadeu Martins Marba) of the CAISM (Center of Integrated Care for Women's Health) University of Campinas for kind support in the care of the patients.

The results presented in this publication are an essential part of the $\mathrm{PhD}$ thesis of EBA, supervised by ILM. (Postgraduate Course in Medical Pathophysiology, University of Campinas)

\section{Author details}

'Department of Internal Medicine, Faculty of Medical Sciences, State University of Campinas, Rua Tessalia Vieira de Camargo 126, 13083-887 Campinas, Brazil. ${ }^{2}$ Department of Gynecology and Obstetrics, Faculty of Medical Sciences, State University of Campinas Av. Alexander Fleming 101, 13083-881 - Campinas, Brazil. ${ }^{3}$ Center for Investigation in Pediatrics - CIPED 
and Department of Pediatrics Faculty of Medical Sciences, State University of Campinas, Rua Tessalia Vieira de Camargo 126, 13083-887 - Campinas, Brazil. ${ }^{4}$ Department of Pathology, Faculty of Medical Sciences, State University of Campinas, Rua Tessalia Vieira de Camargo 126, 13083-887 - Campinas, Brazil. ${ }^{5}$ Hemocentro - State University of Campinas, Rua Carlos Chagas 480, 13083878 Campinas - SP Brazil.

\section{Authors' contributions}

EBA made the data collection and analysis from mothers, performed all the laboratory tests and participated in the data analysis as well as the elaboration of the manuscript. HMPMM was responsible for the selection and treatment of the HIV+ mothers, performed all the deliveries and participated in the elaboration of the draft. MMSV participated in the study design, gave support to all the immunological examinations, and revised the manuscript. FGPC and SCRA supervised the flow cytometric analysis and made its interpretation. BMA collected clinical data from the newborns, made the follow-up of the infants and participated in the data analysis. KM participated in the elaboration of the study design and made all the statistical analysis. ILM made the conception of the study, supervised all the data analysis and elaborated and made the critical revision of the manuscript.

All authors read and approved the final manuscript.

\section{Competing interests}

The authors declare that they have no competing interests.

Received: 26 March 2010 Accepted: 3 February 2011

Published: 3 February 2011

\section{References}

1. Blanche S, Rouzioux C, Moscato MLG, Veber F, Mayaux MJ, Jacomet C, Joëlle Tricoire J, Deville A, Vial M, Firtion G, Crepy A, Douard D, Robin M, Courpotin C, Ciraru-Vigneron N, Deist F, Griscelli C, the HIV Infection in Newborns French Collaborative Study Group: A prospective study of infants born to women seropositive for human immunodeficiency virus type 1. N Engl J Med 1989, 320:1643-1648.

2. Clerici M, Saresella M, Colombo F, Fossati S, Sala N, Bricalli D, Villa ML, Ferrante P, Dally L, Vigano A: T-lymphocyte maturation abnormalities in uninfected newborns and children with vertical exposure to HIV. Blood 2000, 96:3866-3871.

3. Müller F, Tjonnfjord GE, Nordoy I, Kvale D, Mellbye OJ, Aukrust R, Froland SS: Immunophenotypic analyses of CD34+ cell subsets in bone marrow from HIV-infected patients during highly-active antiretroviral therapy. Eur J Clin Invest 2002, 32:535-540.

4. Pacheco SE, McIntosh K, Ming L, Mofenson LM, Diaz C, Foca M, Frederick M, Handelsman E, Hayani K, Shearer WT, Women and Infants Transmission Study: Effect of perinatal antiretroviral drug exposure on hematologic values in HIV-uninfected children: an analysis of the women and infants transmission study. J Infect Dis 2006, 194:1089-1097.

5. Newell ML, Huang S, Fiore S, Thorne C, Mandelbrot L, Sullivan JL, Maupin R, Delke I, Watts DH, Gelber RD, Cunningham CK, PACTG 316 Study Team: Characteristics and management of HIV-1-infected pregnant women enrolled in a randomised trial: differences between Europe and the USA. BMC Infect Dis 2007, 7:60.

6. Sachdeva N, Oshima K, Cotter A, Ashman M, Davila L, Okazaki T, Inaba N, Asthana D: Analysis of immunological markers associated with pregnancy and HIV-1 infection: relevance in perinatal transmission in HIV-1-infected pregnant women with low plasma viral load. Am J Reprod Immunol 2008, 60:264-273.

7. Thorne C, Semenenko I, Pilipenko T, Malyuta R, Ukraine European Collaborative Study Group: Progress in prevention of mother-to-child transmission of HIV infection in Ukraine: results from a birth cohort study. BMC Infect Dis 2009, 9:40.

8. Feola DJ, Garvy BA: Combination exposure to zidovudine plus sulfamethoxazole-trimethoprim diminishes B lymphocyte immune responses to Pneumocystis murina infection in healthy mice. Clin Vaccine Immunol 2006, 13:193-201.

9. Nielsen SD, Jeppesen DL, Kolte L, Clark DR, Sørensen TU, Dreves AM, Ersbøll AK, Ryder LP, Valerius NH, Nielsen JO: Impaired progenitor cell function in HIV-negative infants of HIV-positive mothers results in decreased thymic output and low CD4 counts. Blood 2001, 98:398-404.
10. Ono E, Nunes dos Santos AM, Succi RCM, Machado DM, de Angelis DSA, Salomão R, Kallás EG, de Moraes-Pinto MI: Imbalance of naïve and memory T lymphocytes with sustained high cellular activation during the first year of life from uninfected children born to HIV-1-infected mothers on HAART. Braz J Med Biol Res 2008, 41:700-708.

11. Bunders M, Thorne C, Newell ML, the European Collaborative Study: Maternal and infant factors and lymphocyte, CD4 and CD8 cell counts in uninfected children of HIV-1-infected mothers. AIDS 2005, 19:1071-1079.

12. Zaccarelli-Filho CA, Ono E, Machado DM, Brunialti M, Succi RCM, Salomão R, Kallás EG, de Moraes-Pinto MI: HIV-1-infected children on HAART: immunologic features of three different levels of viral suppression. Cytometry B 2007, 72:14-21.

13. Carniel EF, Morcillo AM, Blotta MH, Da Silva MTN, Mazzola TN, Antonio MA, Zanolli ML, Netto AA, Higashi HG, Raw I, Vilela MM: Immunogenicity and safety of combined intradermal recombinant hepatitis B with BCG vaccines at birth. Vaccine 2008, 26:647-652.

14. Shearer WT, Rosenblatt HM, Gelman RS, Oyomopito R, Plaeger S, Sthiem ER, Wara DW, Douglas SD, Luzuriaga K, McFarland EJ, Yogev R, Rathore MH, Levy W, Graham BL, Spector SA, Pediatric AIDS Clinical Trials Group: Lymphocyte subsets in healthy children from birth through 18 years of age: the pediatrics AIDS Clinical Trials Group P1009 study. J Allergy Clin Immunol 2003, 112:973-980.

15. Fiore S, Newell ML, Trabattoni D, Thorne C, Gray L, Savasi V, Tibaldi C, Ferrazzi E, Clerici M: Antiretroviral therapy-associated modulation of Th1 and Th2 immune responses in HIV-infected pregnant women. J Reprod Immunol 2006, 70:143-150.

16. Adam RL, Silva RC, Pereira FG, Leite NJ, Lorand-Metze I, Metze K: The fractal dimension of nuclear chromatin as a prognostic factor in acute precursor B lymphoblastic leukemia. Cell Oncol 2006, 28:55-59.

17. Rybka MO, Cintra ML, de Souza EM, Metze K: Density of dendritic cells around basal cell carcinomas is related to tumor size, anatomical site and stromal characteristics, and might be responsible for the response to topical therapy. Int J Dermatol 2008, 47:1240-4.

18. Lorand-Metze I, Meira DG, Lima CS, Vassallo J, Metze K: The differential diagnosis between aplastic anemia and hypocellular myelodysplasia in patients with pancytopenia. Haematologica 1999, 84:564-565.

19. Faye A, Pornprasert S, Mary JY, Dolcini G, Derrien M, Barré-Sinoussi F, Chaouat G, Menu E, the ANRS 1267 study team and the HIV-1 PMTCTPlaNet: Characterization of the main placental cytokine profiles from HIV-1-infected pregnant women treated with anti-retroviral drugs in France. Clin Exp Immunol 2007, 149:430-439.

20. Hygino J, Lima PG, Filho RGS, Silva AAL, Saramago CSM, Andrade RM, Andrade DM, Andrade AF, Brindeiro R, Tanuri A, Bento CA: Altered immunological reactivity in HIV-1-exposed uninfected neonates. Clin Immunol 2008, 127:340-347.

21. Resino S, Galán R, Correa R, Pajuelo J, Bellón JM, Munoz-Fernandez MA: Homeostatic role of IL7 in HIV-1 infected children on HAART: association with immunological and virological parameters. Acta Paediatr 2005, 94:170-177.

22. Sadeghi M, Susal C, Daniel V, Naujokat C, Zimmermann R, Huth-Kuhne A, Opelz G: Decreasing soluble CD30 and increasing IFNy plasma levels are indicators of effective highly active antiretroviral therapy. AIDS Res Hum Retrov 2007, 23:886-890.

23. Redgrave $B E$, Stone $S F$, French MAH, Krueger $R$, James IR, Price $P$ : The effect of combination antiretroviral therapy on CD5 B-cells, B-cell activation and hypergammaglobulinaemia in HIV-1-infected patients. HIV Med 2005, 6:307-312.

24. Sampaio A, López-Gómez M, Jimenez-Alonso J, Ortiz F, Samaniego F, Garrido F: CD5+ B lymphocytes in HIV infection: relationship to immunological progression of disease. Clin Immunol Immunopathol 1993, 66:260-268.

25. Meira DG, Lorand-Metze I, Toro ADC, Silva MTN, Vilela MMS: Bone marrow features in children with HIV infection and peripheral blood cytopenias. J Trop Pediatr 2005, 51:114-119.

26. Halonen M, Lohman IC, Stern DA, Spangenberg A, Anderson D, Mobley S, Ciano K, Peck M, Wright AL: Th1/Th2 patterns and balance in cytokine production in the parents and infants of a large birth cohort. I Immunol 2009, 182:3285-3293.

27. Barbaro G, lacobellis G: Metabolic syndrome associated with HIV and highly active antiretroviral therapy. Current Diabetes Reports 2009, 9:37-42. 
28. Pornprasert S, Mary JY, Faye A, Leechanachai P, Limtrakul A, Rugpao S, Sirivatanapa P, Gomuthbutra V, Matanasaravoot W, Le Coeur S, Lallemant M, Barré-Sinoussi F, Menu E, Ngo-Giang-Huong N, ANRS 1267 study team and HIV-1 PMTCT-PlaNet: Higher placental anti-inflammatory IL-10 cytokine expression in HIV-1 infected women receiving longer zidovudine prophylaxis associated with nevirapine. Curr HIV Res 2009, 7:211-217.

29. Shuter J, Bernstein SL: Cigarette smoking is an independent predictor of non-adherence in HIV-infected individuals receiving highly active antiretroviral therapy. Nicotine\&Tobacco Res 2008, 10:731-736.

30. Wojna V, Robles L, Skolasky RL, Mayo R, Selnes O, de la Torre T, Maldonado E, Nath A, Meléndez LM, Lasalde-Dominicci J: Associations of cigarette smoking with viral immune and cognitive function in human immunodeficiency virus- seropositive women. J Neurovirol 2007, 13:561-568.

31. De Maria A, Cirillo C, Moretta L: Occurrence of HIV-1 specific cytolitic T cell activity in apparently uninfected children born to HIV-1 infected mothers. J Infect Dis 1994, 170:1296-1301.

32. Kuhn L, Meddows-Taylor S, Gray G, Tiemessen C: Human immunodeficiency virus (HIV)-specific cellular immune responses in newborns exposed to HIV in utero. Clin Infect Dis 2002, 34:267-276.

33. Malamitsi-Puchner A, Protonotariou E, Boutsikou T, Makrakis E, Sarandakou A, Creatsas G: The influence of the mode of delivery on circulating cytokine concentrations in the perinatal period. Early Human Development 2005, 81:387-392.

34. Malaspina A, Moir S, Ho J, Wang W, Howell ML, O'Shea MA, Roby GA, Rehm CA, Mican JM, Chun TW, Fauci AS: Appearance of immature/ transitional B cells in HIV-infected individuals with advanced disease: correlation with increased IL-7. PNAS 2006, 103:2262-2267.

35. Metze K, Maciel JA Jr: AIDS and Chagas' disease. Neurology 1993, 43:447-448.

36. Viganò A, Zuccotti GV, Pacci M, Erba P, Castelletti E, Giacomet V, Amendola A, Pariani E, Tanzi E, Clerici M: Humoral and cellular response to influenza vaccine in HIV-infected children with full viroimmunologic response to antiretroviral therapy. J Acquir Immune Defic Syndr 2008, 48:289-296.

37. Gary-Gouy H, Harriague J, Bismuth G, Platzer C, Schmitt C, Dalloul AH: Human CD5 promotes B-cell survival through stimulation of autocrine IL-10 production. Blood 2002, 100:4537-4543.

38. Durandy A, Thuillier L, Forveille M, Fischer A: Phenotypic characteristics of human newborns' B lymphocytes. J Immunol 1990, 144:60-65.

39. van Lochen $E G$, van der Velden VHJ, Wind HK, te Marvelde JG, Westerdaal NAC, van Dongen JJM: Immunophenotypic differentiation of normal hematopoiesis in human bone marrow: reference patterns for age-related changes and disease-induced shifts. Cytometry B 2004, 60B:1-13.

40. Karlix J, Behnke M, Davis-Eyler F, Wobie K, Adams V, Freiburger B, Conlon M, Tebbett I: Cocaine Suppresses Fetal Immune System. Ped Res 1998, 44:43-46.

\section{Pre-publication history}

The pre-publication history for this paper can be accessed here: http://www.biomedcentral.com/1471-2334/11/38/prepub

doi:10.1186/1471-2334-11-38

Cite this article as: Borges-Almeida et al:: The impact of maternal HIV infection on cord blood lymphocyte subsets and cytokine profile in exposed non-infected newborns. BMC Infectious Diseases 2011 11:38.

\section{Submit your next manuscript to BioMed Central and take full advantage of:}

- Convenient online submission

- Thorough peer review

- No space constraints or color figure charges

- Immediate publication on acceptance

- Inclusion in PubMed, CAS, Scopus and Google Scholar

- Research which is freely available for redistribution

Submit your manuscript at www.biomedcentral.com/submit 